\title{
Effect of mouse epidermal growth factor on plasma concentrations of FSH, LH and progesterone and on oestrus, ovulation and ovulation rate in Merino ewes
}

\author{
H. M. Radford, B. A. Panaretto, J. A. Avenell and K. E. Turnbull \\ CSIRO, Division of Animal Production, P.O. Box 239, Blacktown, New South Wales 2148, \\ Australia
}

\begin{abstract}
Summary. The $24 \mathrm{~h}$ i.v. infusion of Merino ewes with 60 or $100 \mu \mathrm{g}$ mouse epidermal growth factor (EGF)/kg body weight on Days 4,9 or 14 of the oestrous cycle decreased the strength of wool attachment and caused marked changes in subsequent reproductive performance. In ovaries removed 2 days after EGF treatment all follicles $\geqslant 0.6 \mathrm{~mm}$ diameter were atretic. After 7 days either a normal pattern of atresia or no atresia was evident while after 12 days the pattern of follicular atresia was similar to that in controls. Irrespective of stage of cycle EGF caused dose-dependent increases in plasma FSH concentrations that persisted for up to 14 days. Changes in plasma LH concentrations were generally similar after infusion on Days 4 and 14, but were smaller and shorter-lived after infusion on Day 9.

Irrespective of dose, the infusion of EGF on Days 4 and 14 caused immediate luteolysis then the formation of a luteinized follicle in many ewes. Most ewes treated on Day 4 returned to oestrus between Days 17 and 21 with the same ovulation rate $(1 \cdot 3)$ as the controls. Of those infused on Day 14 oestrus occurred about a cycle length later than expected and their ovulation rate then (1.9) was also similar to that of the controls (1.7). Luteal function was not affected in ewes infused on Day 9, and most returned to oestrus between Days 17 and 20 with an ovulation rate of $3 \cdot 2$. Fertile rams were not placed with the ewes until after the differences in ovulation rate had been observed. Mating occurred generally $2-4$ weeks after treatment, and there were no differences between EGF-treated and control ewes in fertility or fecundity.

The results are interpreted as indicating that mouse EGF induces ovarian follicular atresia but has differential effects on luteal function according to the stage of the oestrous cycle at which it is given. As a consequence of these two effects, which lead to differential changes in gonadotrophin secretion, ovarian function may be temporarily impaired, little affected or improved.
\end{abstract}

\section{Introduction}

Mouse epidermal growth factor (EGF), the 53 amino acid peptide first studied by Levi-Montalcini \& Cohen (1960), has diverse effects on various tissues in many species (King \& Carpenter, 1983). In sheep, mouse EGF is being investigated as a commercial defleecing agent because it weakens wool fibres (Moore et al., 1981). However, mouse EGF has marked effects on some hormones (Waters et al., 1982; Singh Asa \& Waters, 1983; Scoggins et al., 1984; Moore et al., 1984). Shaw et al. (1985) reported that, when sheep were infused intravenously over $24 \mathrm{~h}$ on Day 9 or 10 of the oestrous cycle, a depilatory dose of mouse EGF $(4 \cdot 2 \mu \mathrm{g} / \mathrm{kg} / \mathrm{h})$ had no apparent effect on current luteal function, that plasma FSH concentrations were elevated over succeeding days, and that the next oestrus was delayed. In the same study, mouse EGF given after prostaglandin-induced luteolysis 
led to a similarly timed increase in FSH, reduced oestradiol and $\mathrm{LH}$ secretion, and failure to experience oestrus at the expected time but apparently normal luteal function thereafter. Radford et al. (1987) found that mouse EGF apparently acts on the hypothalamus or higher nervous centres, limiting LHRH release, and thereby $\mathrm{LH}$ release, in ovariectomized ewes, and that the ovaries of anoestrous ewes treated with EGF were temporarily unable to ovulate in response to injected PMSG. The duration and mechanism of the ovarian inhibitions, as reported in the studies of Shaw et al. (1985) and Radford et al. (1987), were investigated here.

\section{Materials and Methods}

\section{Animals and treatment groups}

Mature Merino ewes, known to have lambed in November 1984, and shorn the same month, were used in the autumn (March-April) of 1985. Following the second oestrus after progestagen sponge removal (Repromap: Upjohn, Sydney, Australia), 54 ewes which had experienced oestrus on the same day (Day 0) were selected, with restrictions according to body weight, for treatment on Days 4,9 or 14 of the oestrous cycle. Groups of 6 ewes were treated i.v. for $24 \mathrm{~h}$ with sterile saline $(9 \mathrm{~g} \mathrm{NaCl} / 1)$ or 60 or $100 \mu \mathrm{g}$ mouse EGF/ $\mathrm{kg}$ body weight. There were therefore 9 subgroups, each of 6 ewes.

\section{Preparation and administration of mouse EGF}

Mouse EGF was prepared from mouse submaxillary glands by the method of Savage \& Cohen (1972), and purified (Radford et al., 1987). The EGF was prepared for infusion by dissolving in sterile saline $(9 \mathrm{~g} \mathrm{NaCl} / \mathrm{l})$ (Travenol Laboratories, Sydney, NSW, Australia) to achieve a total infused dose over $24 \mathrm{~h}$ of $60 \mathrm{or} 100 \mu \mathrm{g} / \mathrm{kg}$ body weight. The infusion was made via a jugular cannula at the rate of $12.5 \mathrm{ml} / \mathrm{h}$. Controls received saline only.

\section{Collection of blood samples}

Blood samples $(4 \mathrm{ml})$ were collected from 18 ewes, two from each group, daily from Days 2 to 40 . In addition, 4-ml blood samples were collected from all 54 ewes at intervals of $30 \mathrm{~min}$ to $6 \mathrm{~h}$ before, during and immediately after infusion, and at 15 -min intervals for $2 \mathrm{~h}$ on the 2 nd day after infusion. All blood samples, which were collected by venepuncture into heparinized tubes, were held in ice water until centrifugation within $2 \mathrm{~h}$ of collection and the resultant plasma was stored at $-10^{\circ} \mathrm{C}$ until assayed for $\mathrm{FSH}, \mathrm{LH}$ and progesterone.

\section{Observations on reproductive function}

Oestrus. Except during the period from $24 \mathrm{~h}$ before to $16 \mathrm{~h}$ after infusion all ewes were kept in large pens under cover with vasectomized rams wearing Sire-sine harnesses and crayons (Hortico, Melbourne, Victoria, Australia). The 18 ewes bled daily were run with 2 vasectomized rams as a group, and the remaining 36 ewes were run as a group with 3 vasectomized rams. Daily observations were made for the presence of crayon marks indicative of service. On Day 24 the vasectomized rams were replaced with entire rams which remained with the ewes until Day 60.

Ovarian histology. Nine ewes, one from each group, were ovariectomized on Day 16 and their ovaries placed in a solution of $95 \%$ ethanol: formalin ( $\sim 36 \%$ formaldehyde): glacial acetic acid $(6: 3: 1$ by vol) for $24 \mathrm{~h}$. The ovaries were then stored in $70 \%(\mathrm{v} / \mathrm{v})$ ethanol until being embedded. Each ovary was serially sectioned at $15 \mu \mathrm{m}$, stained with haematoxylin and eosin and examined microscopically. Follicle diameter was measured and mitotic index of the granulosa cells was calculated (Turnbull et al., 1977) for all follicles $>0.3 \mathrm{~mm}$ in diameter; atretic follicles were identified by the presence of pycnotic nuclei within the granulosa.

There were therefore only 45 ewes, 15 control and 30 EGF-treated, remaining for further observations on reproductive function.

Laparoscopic examination of ovaries. The ovaries of the 18 ewes bled daily were examined by laparoscopy under local anaesthesia on Day 18, and those of all 45 on Days 22 and 36-43.

\section{Attachment of wool}

Ten measurements of the strength of attachment (N/kTex) of wool (Gordon, 1980; Gordon \& Pallister, 1981) were made on each ewe before infusion and 5 measurements were made on the 6th day after the start of EGF infusion. 


\section{General husbandry}

The ewes were fed as groups daily a pelletted mixture (60:40 by weight) of lucerne chaff and oats, in amounts sufficient to maintain weight. Water was always available. Since it was known that at least some ewes would shed their wool as a result of the EGF treatment all ewes were machine-shorn 6 or 7 days after infusion. From then until Day 48 they were protected against cold with woven plastic coats (R. J. Davis, Wahroonga, NSW, Australia).

\section{Hormone assays}

All hormones were measured by radioimmunoassay. In the EGF assay (Panaretto et al., 1982), the sensitivity, defined as twice the s.d. of the zero point of the standard curve, was $0.21 \mathrm{ng} / \mathrm{ml}$. The coefficients of variation (CV) for plasma samples with mean concentrations of $5.5,10.8$ and $24.4 \mathrm{ng} / \mathrm{ml}$ were all $<10 \%$. The sensitivity of the LH assay (Radford et al., 1987) ranged from 0.09 to $0.23 \mathrm{ng} / \mathrm{ml}$, and for plasma samples with mean concentrations of $0.9,2.9$ and $5.0 \mathrm{ng} / \mathrm{ml}$ the intra- and inter-assay $\mathrm{CV}$ were $<10 \%$ and $<15 \%$ respectively. Progesterone was measured, after hexane extraction of plasma, essentially as described by Avenell et al. (1985). Standards were prepared in plasma from ovariectomized ewes in which progesterone was undetectable. Sensitivity of the assays was $0.1 \mathrm{ng} / \mathrm{ml}$ and, for 1 plasma sample with a mean concentration of $0.8 \mathrm{ng} / \mathrm{ml}$, the intra- and inter-assay $\mathrm{CV}$ were $<8 \%$ and $<13 \%$ respectively.

FSH was assayed using NIAMDD reagents kindly supplied by Dr A. F. Parlow, Pituitary Hormones and Antisera Center, Torrance, California, U.S.A. Recommendations of the NIAMDD Technical Report 141 were followed except that NIAMDD anti-oFSH1 rabbit serum was used at a final concentration of $1: 280000$ at which it bound $35 \%$ of iodinated tracer hormone. The NIAMDD oFSH-I-1 was iodinated by the method of Avenell et al. (1985). The standard hormone was NIAMDD oFSH-RP-1 diluted in plasma from an oestrogen-treated entire ram. NIAMDD oFSH-RP-1 is about 30 times more potent than NIH-FSH-S10. In the assay system the cross-reactions of the antiserum with other hormones were NIH-TSH-S2, 2\%; NIH-LH-S18, <0.2\%; NIH-GH-S7, NIH-Prolactin-S6, hCG (Sigma), PMSG (Intervet), tetracosactrin, $<0.1 \%$. Serial dilutions of plasmas high in FSH gave curves parallel to that of the reference preparation. Assay sensitivity ranged from 0.06 to $0.13 \mathrm{ng} / \mathrm{ml}$, and for 2 pools of plasma with mean concentrations of 0.9 and $3.9 \mathrm{ng}$ oFSH-RP- $1 / \mathrm{ml}$ the intra- and inter-assay coefficients of variation were all $<10 \%$.

\section{Data analysis}

Differences in hormone concentrations were assessed using Student's $t$ test and differences in proportional responses between treatments were assessed by $\chi^{2}$ analysis. Pulses of LH secretion were defined according to Radford et al. (1987).

\section{Results}

\section{Plasma EGF concentrations and fleece attachment}

There were no differences between ewes infused at different stages of the oestrous cycle in the concentrations of mouse EGF in the plasma. In those infused with $59-62 \mu \mathrm{g} / \mathrm{kg}$ (nominal $60 \mu \mathrm{g} / \mathrm{kg}$ ), plasma EGF concentrations reached $9.5 \pm 0.2 \mathrm{ng} / \mathrm{ml}$ by the end of the infusion, while in the ewes given $96-106 \mu \mathrm{g} / \mathrm{kg}$ (nominal $100 \mu \mathrm{g} / \mathrm{kg}$ ) the concentrations reached $28.2 \pm 1.5 \mathrm{ng} / \mathrm{ml}$. The clearance of EGF was rapid and it would not be detected in plasma $24 \mathrm{~h}$ after cessation of the infusion.

Saline infusion did not affect the strength of attachment of wool to the skin but EGF treatment caused marked decreases. The depilation forces (mean \pm s.e.m.) before treatment in the ewes infused with 60 and $100 \mu \mathrm{g} \mathrm{mEGF} / \mathrm{kg}$ were $20 \cdot 0 \pm 2.0$ and $19 \cdot 3 \pm 1 \cdot 5 \mathrm{~N} / \mathrm{kTex}$, respectively. At 6 days after the start of infusion they were $2.6 \pm 0.1$ and $1.1 \pm 0.2 \mathrm{~N} / \mathrm{kTex}$. At this time 3 ewes at the lower dosage and 5 at the higher dosage were shedding parts of their fleeces.

\section{Occurrence of oestrus}

Of the 15 control ewes, 14 experienced oestrus within 16-18 days of their pretreatment oestrus but oestrus was within this range in only 6 of the 30 EGF-treated ewes (Table 1). In another 9, 8 of which had received $100 \mu \mathrm{gEGF} / \mathrm{kg}$, the range was $20-21$ days and in one 15 days, but none of the remaining 14 ewes experienced oestrus before Day 24 . 
Table 1. Effect of mouse EGF infused over $24 \mathrm{~h}$ on occurrence of oestrus and ovulation rate in sheep

\begin{tabular}{|c|c|c|c|c|c|c|}
\hline \multirow{3}{*}{$\begin{array}{c}\text { Dose } \\
(\mu \mathrm{g} \mathrm{EGF} / \mathrm{kg})\end{array}$} & \multirow{3}{*}{$\begin{array}{l}\text { Day of } \\
\text { treatment }\end{array}$} & \multirow{3}{*}{$\begin{array}{l}\text { No. of } \\
\text { ewes }\end{array}$} & \multicolumn{2}{|c|}{ Intervals to oestrus (days) } & \multirow{2}{*}{\multicolumn{2}{|c|}{$\begin{array}{l}\text { No. of } \\
\text { corpora lutea } \\
\text { in ovaries }\end{array}$}} \\
\hline & & & \multirow{2}{*}{$\begin{array}{l}\text { Pretreatment } \\
\text { oestrus to first } \\
\text { oestrus after } \\
\text { treatment }\end{array}$} & \multirow{2}{*}{$\begin{array}{c}\text { First to } \\
\text { second } \\
\text { oestrus after } \\
\text { treatment }\end{array}$} & & \\
\hline & & & & & Day 22 & $36-43$ \\
\hline 0 & $4,9,14$ & 15 & $16-18(14), 20$ & $16-18(15)$ & $1 \cdot 3 \pm 0 \cdot 1$ & $1 \cdot 7 \pm 0 \cdot 1$ \\
\hline 60 & $\begin{array}{r}4 \\
9 \\
14\end{array}$ & $\begin{array}{l}5 \\
5 \\
5\end{array}$ & $\begin{aligned} 15-18 & (3), 21,27 \\
17 & (3), 33,35 \\
30-36 & (5)\end{aligned}$ & $\begin{array}{r}16-17 \quad(4) \\
17(3) \\
19(1)\end{array}$ & $\begin{array}{l}1 \cdot 6 \pm 0.5 \\
3 \cdot 0 \pm 0.5 \\
0.2 \pm 0.2^{(3)}\end{array}$ & $\begin{array}{l}1.6 \pm 0.2 \\
2.2 \pm 0.2 \\
1.6 \pm 0.2\end{array}$ \\
\hline 100 & $\begin{array}{r}4 \\
9 \\
14\end{array}$ & $\begin{array}{l}5 \\
5 \\
5\end{array}$ & $\begin{array}{l}20-21 \quad(4), 25 \\
17,20(4) \\
24,30-34(4)\end{array}$ & $\begin{array}{l}16-18 \quad(4) \\
15-18 \quad(5) \\
17-18 \quad(2)\end{array}$ & $\begin{array}{c}1 \cdot 0 \pm 0.4^{(1)} \\
3 \cdot 4 \pm 0 \cdot 5 \\
0^{(4)}\end{array}$ & $\begin{array}{l}1 \cdot 6 \pm 0.2 \\
2 \cdot 0 \pm 0.0 \\
2 \cdot 2 \pm 0.6^{(1)}\end{array}$ \\
\hline
\end{tabular}

Figures in parentheses indicate no. of ewes.

Superscript figures refer to no. of ewes with a luteinized follicle.
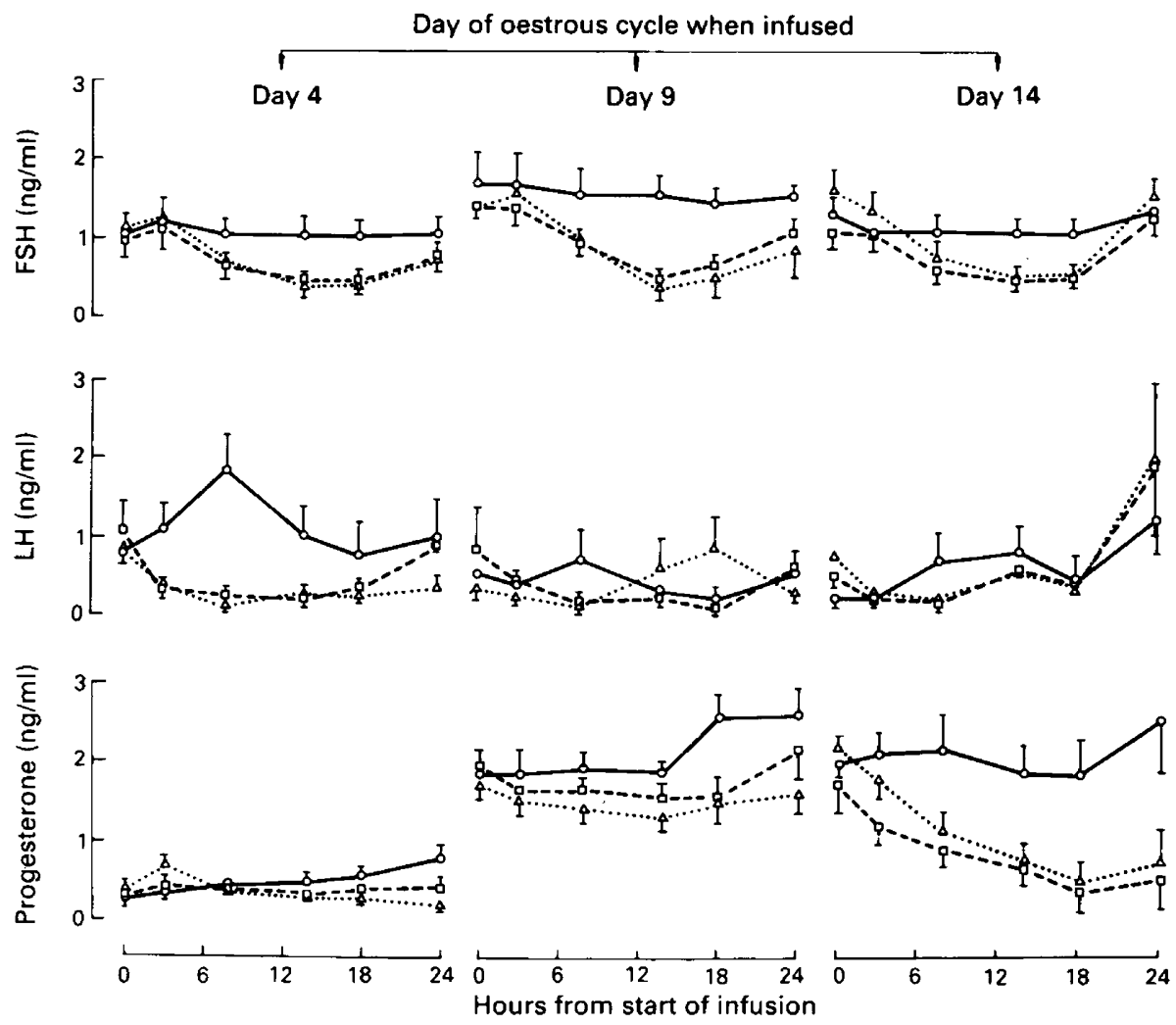

Fig. 1. Changes in concentrations of FSH, $\mathrm{LH}$ and progesterone, during the 24-h infusion of saline $(\bigcirc-O), 60 \mu \mathrm{g}$ mouse $\mathrm{EGF} / \mathrm{kg}(\square--\square)$, or $100 \mu \mathrm{g}$ mouse EGF/kg $(\triangle \cdots \triangle)$. Vertical bars indicate s.e.m. for 6 ewes per treatment. 
There was no significant difference between control and EGF-treated ewes in the interval between the first and second oestrous periods after treatment.

\section{Ovarian examinations}

Day 18 (daily-bled animals only). Of the 6 control ewes, 2 had single recent ovulations. Of the 6 ewes infused with $60 \mu \mathrm{g} \mathrm{EGF} / \mathrm{kg}, 3$ also had ovulated recently: 2 were Day 4-infused ewes, in which the corpora lutea were estimated to be 3-4 days of age (there were 4 such corpora lutea in one of these ewes) and 1 was infused on Day 14. None of the 6 ewes infused with $100 \mu \mathrm{g} \mathrm{EGF} / \mathrm{kg}$ had ovulated recently and in all those infused on Days 4 and 14, a luteinized follicle was present.

Day 22. All control ewes had ovulated, each having 1 or 2 corpora lutea (Table 1), the overall ovulation rate being 1·3. Most of the ewes infused with EGF on Day 4 also had 1 or 2 corpora lutea while most of those infused on Day 14 had a luteinized follicle.

All ewes infused with EGF on Day 9 had 2-5 corpora lutea in the ovaries, ovulation rate $3 \cdot 2$, the corpora lutea being of similar age to those in the controls in 5 ewes, but originating from more recent ovulation in the other 5 .

Day 36-43. There were no statistically significant differences between treatments in the number of corpora lutea present in the ovaries (Table 1).

\section{Changes in concentrations of FSH, LH and progesterone during infusion of EGF}

Plasma FSH concentrations did not change during the infusion of saline. However, during treatment with each dose of EGF, FSH concentration fell during the first $14-18 \mathrm{~h}(t \nless 2 \cdot 54$, d.f. $=10, P<0.05$ ) and then rose to approximate initial values by the end of infusion (Fig. 1). There was a similar depression of LH during infusion of EGF on Day 4, but consistent falls were not evident on Days 9 and 14. During the infusion of either dose of EGF on Days 4 and 9 there was no significant change in plasma progesterone concentrations whereas in the control ewes progesterone concentrations increased $(\mathrm{t} \nless 2.24$, d.f. $=10, P<0.05)$. On Day 14, however, progesterone concentration remained unchanged in control ewes but decreased significantly $(\mathrm{t} \nless 2 \cdot 38$, d.f. $=10$, $P<0.05)$ in the EGF-infused ewes.

\section{Hormone concentration profiles in plasma collected daily}

Control ewes. The patterns of change in the concentrations of FSH, LH, and progesterone were consistent with published evidence on the changes in these hormones throughout the oestrous cycle in the ewe (e.g. Pant et al., 1977).

EGF-infused ewes. Plasma FSH concentrations increased after EGF infusion, irrespective of day of treatment, the duration of the increase being dose dependent (Figs $2 \& 3$ ). Similar changes in plasma LH concentration occurred in the ewes infused on Days 4 and 14 but in those infused on Day 9 the increases were smaller and of shorter duration (Fig. 2). This differential response is reflected in the large standard errors for LH concentrations in Fig. 3 and is evident also in the results presented in the following section. There was cessation of progesterone secretion in most ewes infused with EGF on Days 4 and 14 but no lasting effect in those infused on Day 9 (Fig. 2).

\section{Pattern of LH secretion 2 days after $m E G F$ infusion (Fig. 4)}

Ewes infused on Day 4. Basal concentrations of $\mathrm{LH}$ in the control ewes were around $1 \mathrm{ng} / \mathrm{ml}$, and the amplitude of the pulses, which occurred at a frequency of less than 1 per $2 \mathrm{~h}$, did not exceed $2 \mathrm{ng} / \mathrm{ml}$. By contrast all but 1 EGF-treated ewe had higher basal levels $(2-7 \mathrm{ng} / \mathrm{ml})$, higher pulse frequency, at least 1 per $\mathrm{h}$, and higher pulse amplitude (up to $15 \mathrm{ng} / \mathrm{ml}$ ). 
(Iس/6u) HS」
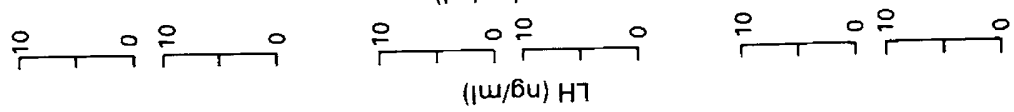

오
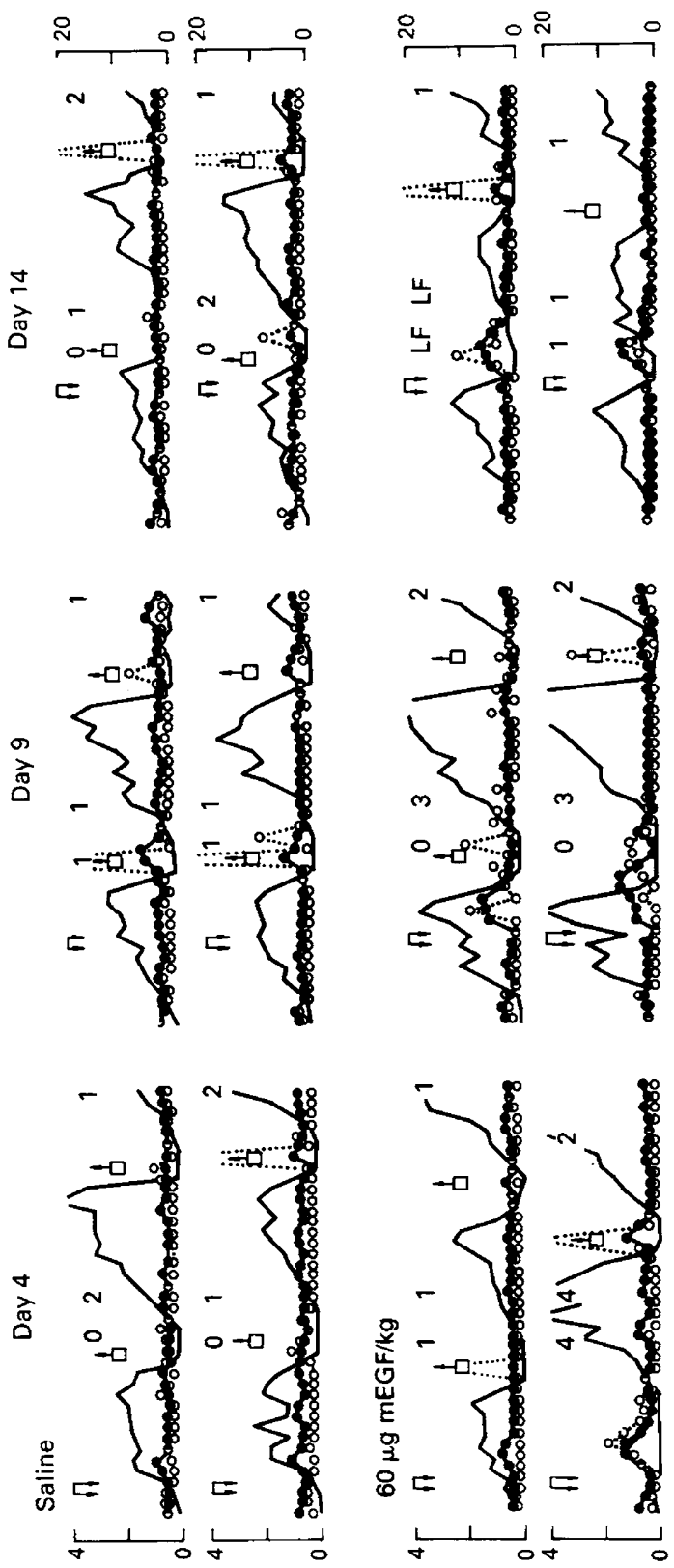

กิ
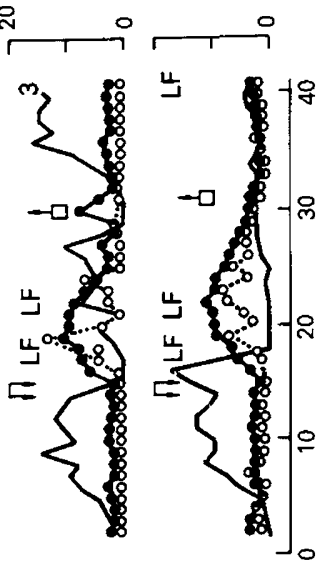

兽离

$\lesssim Z$

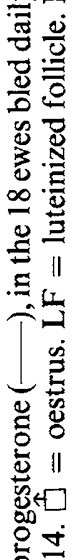

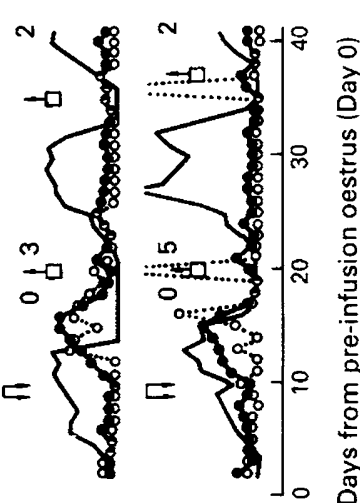

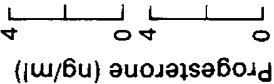

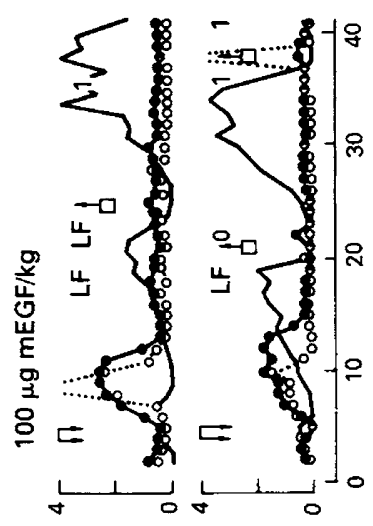

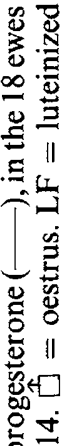

त छั

(ิ)

$0 \stackrel{\infty}{2}$

$\vdots$ ด็

○

至

至造

I

论

동

귬

焉语

苍递

.

\&

要焉

ठำ

i.

舟㟔是 
Ewes infused on Day 9. Irrespective of treatment basal concentrations of LH were $<1 \mathrm{ng} / \mathrm{ml}$. Pulse frequency in the control ewes was $<1$ per $2 \mathrm{~h}$ while in those given EGF it was about 1 per $2 \mathrm{~h}$.

Ewes infused on Day 14. In many of the EGF-treated ewes the pattern of LH secretion was similar to that in the ewes given EGF on Day 4, i.e. relatively high-amplitude pulses (up to $15 \mathrm{ng} / \mathrm{ml}$ ), at a frequency of about 1 per $\mathrm{h}$. Much smaller amplitude pulses, at a similar frequency, occurred in 5 of the control ewes, but both frequency and amplitude of pulses were higher in the other.
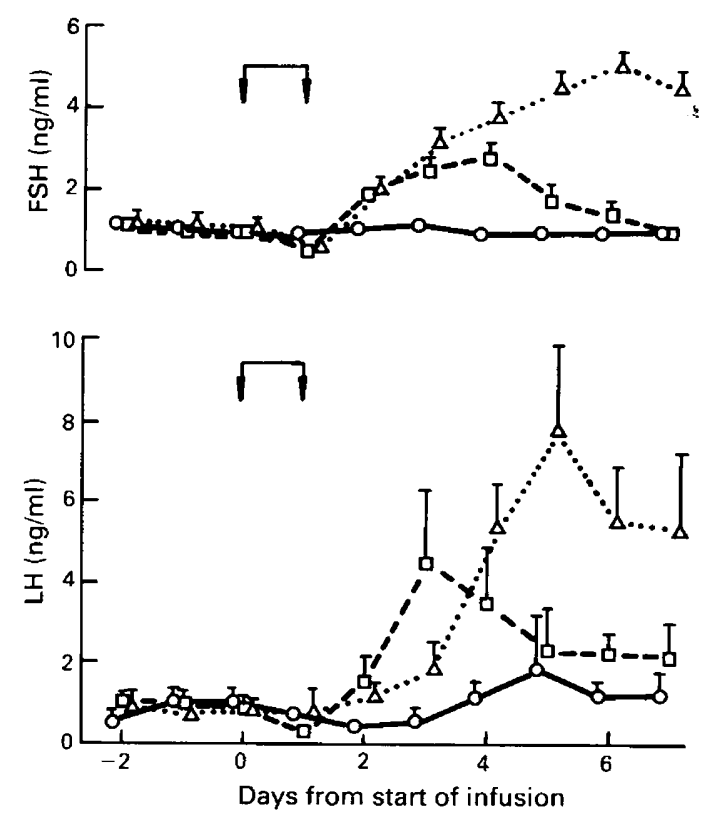

Fig. 3. Changes in concentrations of FSH and LH (mean \pm s.e.m.) in ewes bled daily after infusion $(\downarrow-\downarrow)$ of $0(\bigcirc-O), 60 \mu \mathrm{g}(\square--\square)$ or $100 \mu \mathrm{g}(\triangle \cdots \triangle)$ mouse EGF/kg. Results pooled for the 3 times of infusion; 6 ewes per treatment.

\section{Histological examination of ovaries removed on Day 16}

Ovaries removed 2 days after infusion. All follicles $>0.58 \mathrm{~mm}$ diameter (class 6 , Turnbull et al., 1977) were atretic in the ewe given $60 \mu \mathrm{g} \mathrm{EGF} / \mathrm{kg}$. In the ewe given $100 \mu \mathrm{g} \mathrm{EGF} / \mathrm{kg}$ one large follicle had hypertrophied granulosa cells, indicative of luteinization, and a metaphase plate was present in the contained oocyte, but all other follicles $>0.44 \mathrm{~mm}$ (class 5) were atretic. By contrast only $60 \%$ of all follicles $>1.0 \mathrm{~mm}$ diameter were atretic in the control ewes, and no follicle showed evidence of luteinization. There was a regressing corpus luteum in each ewe, the regression being more advanced in the EGF-treated ewes than in the control ewe.

Ovaries removed 7 days after infusion. The pattern of follicular growth in the ewe given $60 \mu \mathrm{g}$ $\mathrm{EGF} / \mathrm{kg}$ was similar to that in the controls and $65 \%$ of all follicles $>1.0 \mathrm{~mm}$ were atretic. By

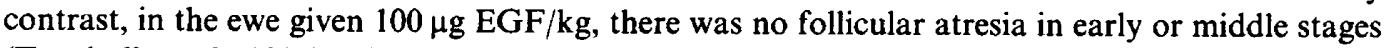
(Turnbull et al., 1977). The largest non-atretic follicles present in the treated ewes were $3.3 \mathrm{~mm}$ $(60 \mu \mathrm{g} \mathrm{EGF} / \mathrm{kg})$ and $2 \cdot 8 \mathrm{~mm}(100 \mu \mathrm{g} \mathrm{EGF} / \mathrm{kg})$ in diameter compared with $5.0 \mathrm{~mm}$ in the controls. 

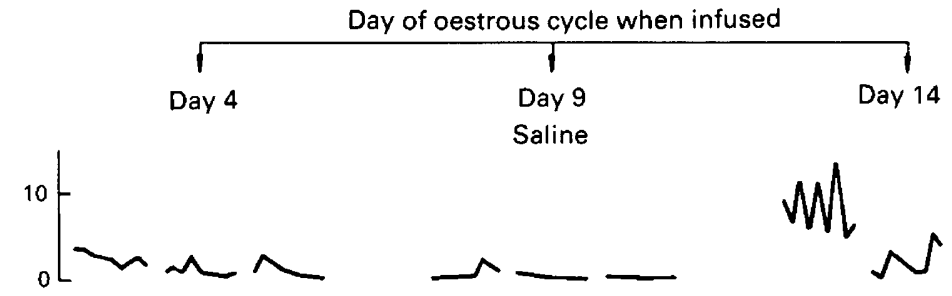

Saline
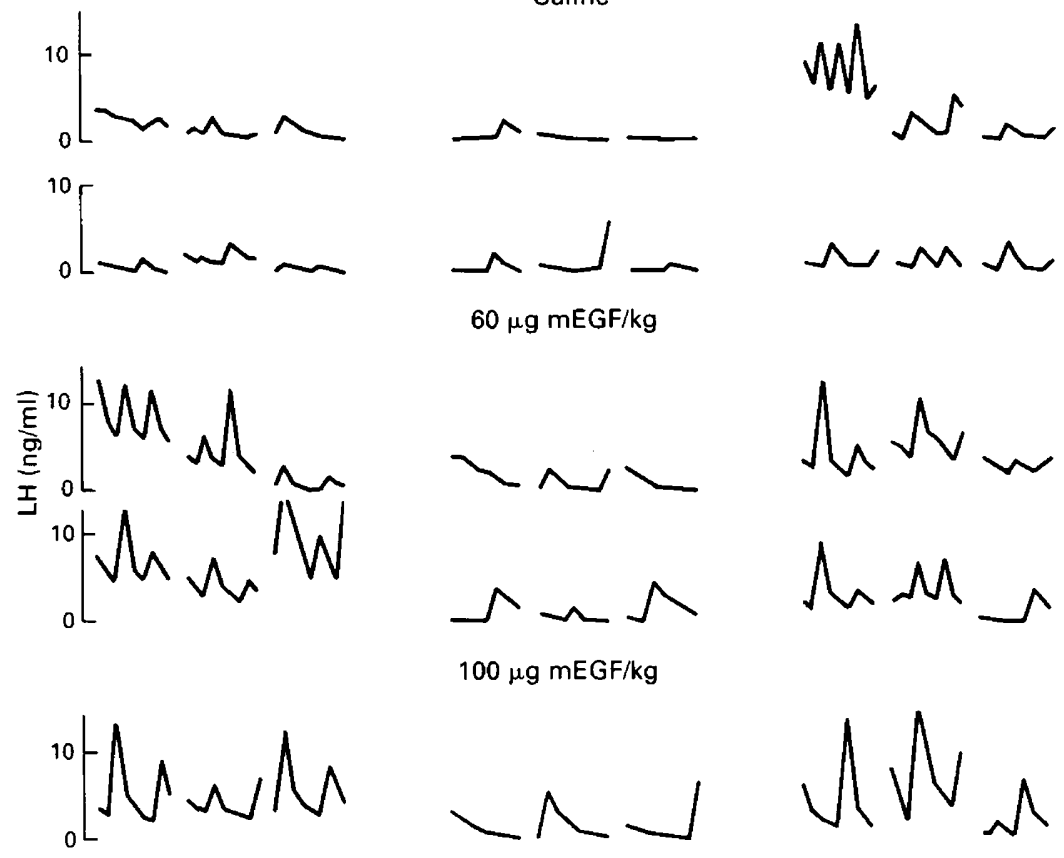

$$
\text { ...m }
$$
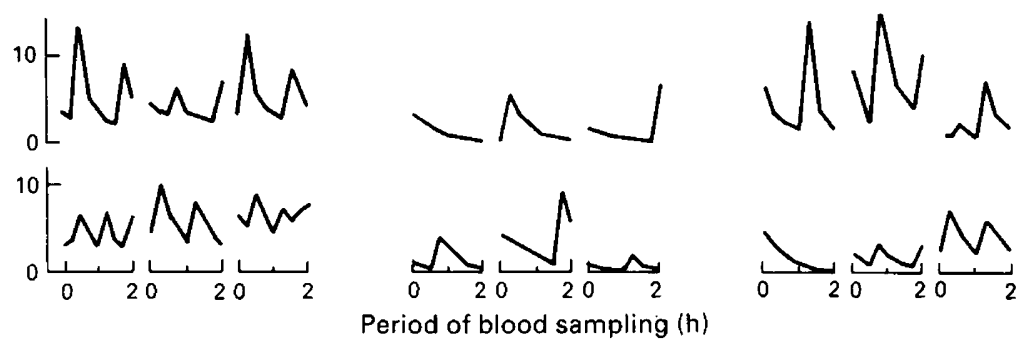

Fig. 4. Changes in concentrations of LH in plasma samples collected every $15 \mathrm{~min}$ for $2 \mathrm{~h}$ for all 54 ewes, 2 days after infusion of saline or mouse EGF.

For follicles $>0.7 \mathrm{~mm}$ in diameter there were fewer granulosa cells in the EGF-treated than in control ewes, the slopes of the regression lines between $\log$ follicle diameter and granulosa volume being $1.53 \pm 0.06$ for the EGF-treated ewes and $1.78 \pm 0.05$ for the controls $(t=24.08$, d.f. $=96$ $P<0.001)$. The mitotic index of the granulosa cells was larger in the EGF-treated than the control ewes, $1 \cdot 13 \pm 0.03$ and $1.02 \pm 0.03$ respectively $(t=2.61$, d.f. $=88, P<0.02)$. There was a corpus luteum, in the same state of regression, in each of the ewes.

Ovaries removed 12 days after infusion. There were no differences between EGF-treated and control ewes in patterns of follicular growth. Two developing corpora lutea were present in the ovaries of each EGF-treated ewe. From their size and morphology it was estimated that ovulation had occurred on about Day 12 in the ewe given $60 \mu \mathrm{g} E \mathrm{GF} / \mathrm{kg}$ and about Day 14 in the ewe given $100 \mu \mathrm{g} \mathrm{EGF/kg.}$

\section{Fertility}

There were no differences between control and mEGF treated ewes in fertility or fecundity (Table 2). 
Table 2. Fertility and fecundity of control and mouse EGF-treated ewes after introduction of entire rams on Day 24

\begin{tabular}{|c|c|c|c|c|c|c|c|}
\hline \multirow[b]{3}{*}{$\begin{array}{c}\text { Dose } \\
(\mu \mathrm{g} \mathrm{EGF/kg)}\end{array}$} & \multicolumn{3}{|c|}{ No. of ewes } & & & & \multirow{3}{*}{$\begin{array}{c}\text { No. } \\
\text { survived } \\
\text { to } 3 \text { weeks }\end{array}$} \\
\hline & & \multicolumn{2}{|c|}{ Conceived at: } & \multicolumn{3}{|c|}{ No. of lambs born } & \\
\hline & & $\begin{array}{c}\text { lst } \\
\text { oestrus }\end{array}$ & $\begin{array}{l}\text { 2nd } \\
\text { oestrus }\end{array}$ & $\begin{array}{c}\text { As } \\
\text { singles }\end{array}$ & $\begin{array}{c}\text { As } \\
\text { twins }\end{array}$ & Males & \\
\hline 0 & 15 & 14 & 0 & 4 & 18 & 9 & 19 \\
\hline 60 & 15 & 14 & 0 & 6 & 16 & 11 & 19 \\
\hline 100 & 15 & 13 & 2 & 10 & 10 & 13 & 17 \\
\hline
\end{tabular}

\section{Discussion}

This study shows that the treatment of normal cyclic Merino ewes with doses of mouse EGF that decreased the strength of attachment of wool to the skin also caused significant changes in reproductive function.

Considerable follicular atresia was evident in the ovaries of ewes 2 days after EGF treatment, its extent being apparently a function of the dose of EGF. We have since confirmed this effect and found that with lower doses of EGF $(37.5 \mu \mathrm{g} / \mathrm{kg}$ body weight) the atresia involves follicles down to about $2 \mathrm{~mm}$ diameter (unpublished data). The cause of the atresia is unknown. It is unlikely to have resulted from any lowered secretion of gonadotrophins since Radford et al. (1987) showed that, even when gonadotrophin secretion was maintained by GnRH injections throughout a period of EGF treatment, the ovaries of such treated ewes failed to respond to exogenous gonadotrophin given 2 days later. It seems likely that the mouse EGF acted directly on the ovary. Mouse EGF has been shown to inhibit steroidogenesis in cultured rat granulosa cells (Gospodarowicz \& Birdwell, 1977; Hsueh et al., 1981) in which EGF receptors have been reported (St-Arnaud et al., 1983).

Follicular atresia would be expected to cause immediate reductions in the secretion of androstenedione, oestradiol and inhibin. Inhibin is currently considered a major regulator of FSH secretion (Franchimont et al., 1981; Channing et al., 1982), and atretic follicles have lower concentrations of inhibin than non-atretic follicles (Henderson et al., 1984). Reduced inhibin concentrations may therefore have been responsible for the post-infusion increases in circulatory FSH concentrations reported here, and by Shaw et al. (1985), although lowered oestradiol concentrations also cannot be discounted as a cause.

Treatment at the different times of the cycle caused differential changes in luteal function. The reasons are not known. The differential effect was evident from the low progesterone concentrations on days after EGF treatment on Days 4 or 14, whereas after infusion on Day 9 progesterone concentrations were similar to those in control ewes (Fig. 2). Further support comes from the patterns of LH concentrations 2 days after infusion. The frequency of $\mathrm{LH}$ release in ewes during the breeding season is regulated principally by progesterone (Goodman \& Karsch, 1980). In many of the ewes treated with mouse EGF on Days 4 and 14 the frequency of LH release was higher than in the controls, indicating impairment of luteal function. In ewes treated on Day 9, however, there was little difference between control and treated ewes, implying no change in luteal function.

The formation of luteinized follicles after infusion of mouse EGF was similarly dependent on the stage of cycle. Luteinized follicles developed in most Day 14-infused ewes in which the hormonal changes immediately after infusion were indicative of both luteolysis and increased $\mathrm{LH}$ secretion. Undoubtedly this increased $\mathrm{LH}$ was responsible for the follicular luteinization. Similar hormonal changes followed the infusion of mouse EGF on Day 4, and it seems likely that a luteinized follicle developed in most of these ewes also, although laparoscopy was inappropriately 
timed to confirm it. There was no evidence of follicular luteinization after mouse EGF infusion on Day 9.

Folliculogenesis in the ewe is continuous (Turnbull et al., 1977; Cahill et al., 1979; Cahill \& Mauléon, 1980). Accordingly the minimum interval between EGF treatment and the next oestrus and ovulation will be a function of the maturity of follicles that escape EGF-induced atresia. At 2 days after mouse EGF treatment at 60 and $100 \mu \mathrm{g} / \mathrm{kg}$ the only follicle showing no evidence of atresia were smaller than those in classes 5 and 4 respectively or were in these classes (Turnbull et al., 1977). Follicles in these classes require an interval of about 8 and 10 days respectively to reach ovulable size.

Most of the ewes infused with mouse EGF on Day 4 experienced oestrus when expected or several days later, with an ovulation rate similar to that in the controls. This probably reflected normal follicular maturation after regression of a luteinized follicle that formed shortly after treatment. Four of the ewes did, however, ovulate around Days 12-15 (the 2 ewes ovariectomized on Day 16 and 2 of the 4 examined by laparoscopy on Day 18). This 8-11-day interval from treatment to ovulation is consistent with the growth rate of class 45 follicles through to ovulation.

Most ewes infused with mouse EGF on Day 9 experienced oestrus when expected or several days after mouse EGF treatment at 60 and $100 \mu \mathrm{g} / \mathrm{kg}$ the only follicles showing no evidence of tion still could not occur within about 8-11 days of treatment because of the time required for development of unaffected class $4-5$ follicles. The apparent time of ovulation, and of oestrus when it occurred, in all 10 ewes is consistent with this explanation. The increased ovulation rate was associated with higher than normal concentrations of FSH and LH during follicular maturation. Whether either or both were causal is unknown. However, at 7 days after EGF treatment, follicles $>0.7 \mathrm{~mm}$ in diameter had fewer granulosa cells than did those of control ewes and the mitotic index of the cells was higher than that in controls. This is a response similar to that seen in PMSGtreated ewes (Turnbull et al., 1977), suggesting an involvement of FSH. The suggestion is supported by evidence from the study of D. T. Baird, A. S. McNeilly, J. M. Wallace \& R. Webb (personal communication), in which FSH infused during the late luteal and/or early follicular phase increased ovulation rate in ewes.

None of the ewes infused with mouse EGF on Day 14 experienced oestrus during the next several days, a result identical to that obtained by Shaw et al. (1985) who showed also that oestradiol was not secreted during this period. In most ewes infused on Day 14 in this study, the resulting luteinized follicle secreted progesterone over a period roughly equivalent to that of a normal corpus luteum. That luteinized follicles and corpora lutea secrete similar amounts of progesterone has also been reported by Murdoch \& Dunn (1983). This explains the apparent lack of difference in luteal function between EGF-treated and control ewes reported by Shaw et al. (1985). Most Day 14-infused ewes did not experience oestrus or ovulate until about one cycle length later than expected, with an ovulation rate similar to that in control ewes. This would be expected since the follicles that ovulated then would have developed against a background of gonadotrophin secretion little different from that in the controls.

Mouse EGF can induce maturation of rat oocytes (Dekel \& Sherizly, 1985) and a metaphase plate was present in an oocyte 2 days after mouse EGF treatment in this study. However, normal fertility followed mating 10-34 days after treatment, indicating that mouse EGF does not affect oocytes within those follicles capable of continued development.

The present study indicates that the reproductive response of Merino ewes to mouse EGF treatment varies according to the stage of the oestrous cycle at which it is given. The increased ovulation rate seen in this study in ewes treated at mid-cycle is being investigated, as is also the mechanism whereby mouse EGF induces the follicular atresia which precedes, and is undoubtedly responsible for, the subsequent superovulatory response.

We thank P. H. Van Dooren for preparing the mouse EGF and P. R. Stockwell and S. Carter for additional technical assistance. 


\section{References}

Avenell, J.A., Saepudin, Y. \& Fletcher, I.C. (1985) Concentrations of luteinizing hormone, oestradiol-17 $\beta$ and progesterone in the peripheral plasma of swamp buffalo cows around the time of oestrus. $J$. Reprod. Fert. 74, 419-424.

Cahill, L.P. \& Mauléon, P. (1980) Influences of season, cycle and breed on follicular growth rates in sheep. $J$. Reprod. Fert. 58, 321-328.

Cahill, L.P., Mariana, J.C. \& Mauléon, P. (1979) The total follicular populations in ewes of high and low ovulation rates. J. Reprod. Fert. 55, 27-36.

Channing, C.P., Anderson, I.D., Hoover, D.J., Kolena, J., Osteen, K.G., Pomerantz, S.H. \& Tanabe, K. (1982) The role of nonsteroidal regulators in control of oocyte and follicular maturation. Recent Prog. Horm. Res. 38, 331-408.

Dekel, N. \& Sherizly, I. (1985) Epidermal growth factor induces maturation of rat follicle-enclosed oocytes. Endocrinology 116, 406-409.

Franchimont, P., Henderson, K., Verhowen, G., HazeeHagelstein, M.T., Charlet-Renard, C., Demoulin, A., Bauguignow, J.P. \& Lecomte-Yerna, M.J. (1981) Inhibin: mechanisms of action and secretion. In Intragonadal Regulation of Reproduction, $\mathrm{pp}$. 167-191. Eds P. Franchimont \& C. P. Channing. Academic Press, London.

Goodman, R.L. \& Karsch, F.J. (1980) Pulsatile secretion of luteinizing hormone: differential suppression by ovarian steroids. Endocrinology 107, 1286-1290.

Gordon, A.J. (1980) The measurement of, and factors affecting, the strength of attachment of wool to the skin of sheep. Aust. J. exp. Agric. Anim. Husb. 20, $40-49$.

Gordon, A.J. \& Pallister, E. (1981) A hand-held device for rapid measurement of wool staple thickness. $J$. Textile Inst. 72, 145-146.

Gospodarowicz, D., III, C.R. \& Birdwell, C.R. (1977) Effects of fibroblast and epidermal growth factor on ovarian cell proliferation: characterization of the response of granulosa cells to FGF and EGF. Endocrinology 100, 1108-1120.

Henderson, K.M., Franchimont, P., Charlet-Renard, Ch. \& McNatty, K.P. (1984) Effect of follicular atresia on inhibin production by bovine granulosa cells in vitro and inhibin concentrations in the follicular fluid. $J$. Reprod. Fert. 72, 1-8.

Hsueb, A.J.W., Welsh, T.H. \& Jones, P.B.C. (1981) Inhibition of ovarian and testicular steroidogenesis by epidermal growth factor. Endocrinology 108, 2002-2004.

King, L.E., Jr \& Carpenter, G.F. (1983) Epidermal growth factor. In Biochemistry and Physiology of the Skin, pp. 269-281. Ed. L. A. Goldsmith. Oxford University Press, New York.

Levi-Montalcini, R. \& Cohen, S. (1960) Effect of the extract of the mouse submaxillary glands on the sympathetic system of mammals. Ann. N.Y. Acad. Sci. 85, 324-341.
Moore, G.P.M., Panaretto, B.A. \& Robertson, D. (1981) Epidermal growth factor causes shedding of the fleece in Merino sheep. Search 12, 128-129.

Moore, G.P.M., Panaretto, B.A. \& Wallace, A.L.C. (1984) Treatment of ewes at different stages of pregnancy with epidermal growth factor: effects on wool growth and plasma concentrations of growth hormone, prolactin, placental lactogen and thyroxine and on foetal development. Acta endocr., Copenh. $105,558-566$.

Murdoch, W.J. \& Dunn, T.G. (1983) Luteal function after ovulation blockade by intrafollicular injection of indomethacin in the ewe. J. Reprod. Fert. 69, 671-675.

Panaretto, B.A., Moore, G.P.M. \& Robertson, D.M. (1982) Plasma concentrations and urinary excretion of mouse epidermal growth factor associated with the inhibition of food consumption and of wool growth in Merino wethers. J. Endocr. 94, 191-202.

Pant, H.C., Hopkinson, C.R.N. \& Fitzpatrick, R.J. (1977) Concentration of oestradiol, progesterone, luteinizing hormone and follicle-stimulating hormone in the jugular venous plasma of ewes during the oestrous cycle. J. Endocr. 73, 247-255.

Radford, H.M., Avenell, J.A. \& Panaretto, B.A. (1987) Some effects of epidermal growth factor on reproductive function in Merino sheep. J. Reprod. Fert. 80, 113-118.

Savage, C.R., Jr \& Cohen, S. (1972) Epidermal growth factor and a new derivative. Rapid isolation procedures and biochemical and chemical characterization. J. biol. Chem. 247, 7609-7611.

Scoggins, B.A., Coghlan, J.P., Cogiu, M., Fei, D.T., McDougall, J.G., Niall, H.D., Wang, X., Barr, P., Merriweather, J.P. \& Valenzuela, P. (1984) Mouse and human epidermal growth factor have hemodynamic effects and stimulate ACTH secretion in sheep. Proc. Endocr. Soc. Austr. 27, 63, Abstr.

Shaw, G., Jorgenson, G.I., Tweedale, R., Tennison, M. \& Waters, M.J. (1985) Effect of epidermal growth factor on reproductive function in ewes. J. Endocr. 107, $429-436$.

Singh-Asa, P. \& Waters, M.J. (1983) Stimulation of adrenal cortisol biosynthesis by epidermal growth factor. Molec. cell. Endocr. 30, 189-199.

St-Arnaud, R., Walker, P., Kelly, P.A. \& Labrie, F. (1983) Rat ovarian epidermal growth factor receptors: characterization and hormonal regulation. Molec. cell. Endocr. 31, 43-52.

Turnbull, K.E., Braden, A.W.H. \& Mattner, P.E. (1977) The pattern of follicular growth and atresia in the ovine ovary. Aust. J. biol. Sci. 30, 229-241.

Waters, M.J., Corcoran, J., Tennison, M.M., Jorgensen, G., Eastman, R.C., Bourke, J.R. \& Thorburn, G.D. (1982) Effects of EGF on endocrine parameters in the ewe. Proc. Endocr. Soc. Austr. 25, 34, Abstr.

Received September 1986 